\title{
PROFIL KEPERIBADIAN MAHASISWA BIMBINGAN DAN KONSELING MENUJU PROFESI MASA DEPAN
}

\author{
Dede Rahmat Hidayat \\ e-mail: d_r_hidayat@yahoo.com \\ Psikologi FIP Universitas Negeri Jakarta
}

\begin{abstract}
Abstrak: Penelitian ini bertujuan memetakan profil kepribadian mahasiswa Jurusan Bimbingan Konseling Fakultas Ilmu Pendidikan Universitas Negeri Jakarta. Penelitian yang dilakukan di Jurusan Bimbingan dan Konseling, Fakultas Ilmu Pendidikan Universitas Negeri Jakarta, pada bulan Juli sampai dengan September 2008, merupakan penelitian deskriptif dengan pendekatan kuantitatif. Populasi penelitian adalah 107 mahasiswa reguler yang terdaftar di Jurusan Bimbingan Konseling pada tahun 2008. Sampel dipilih dengan menggunakan teknik acak proporsional. Data dikumpulkan dengan menggunakan angket Mini Markers. Hasil penelitian menunjukan, berdasarkan teori Big Five Personality, sifat kepribadian yang menonjol adalah kedapatsetujuan dan yang paling rendah adalah kehati-hatian.
\end{abstract}

Kata kunci : profil kepribadian, Big Five Personality, kedapatsetujuan, kehati-hatian, profesi masa depan

\section{STUDENTS' PERSONALITY PROFILE IN THE GUIDANCE AND COUNSELING DEPARTMENT TO FACE FUTURE PROFESSION}

\begin{abstract}
This research aims to map the students' personality profile in the guidance and Counseling Department, School of Education, State University of Jakarta. The research, conducted as from July through September 2008, belongs to descriptive research with quantitative approach. The total population covered 107 regular students registered at the Department in 2008. The samples were appointed by using proporsional random sampling technique. The data were collected applying Mini Markers anquete and anylized statistically. The results indicate, based on Big Five Personality theory the prominant personality character is agreeableness and the lowest is carefulness.
\end{abstract}

Keywords: personality profile, Big Five Personality, agreeableness, carefulness, future profession

\section{PENDAHULUAN}

Setiap profesi memiliki tuntutan dan persyaratan kepada setiap orang yang akan memasukinya. Syarat ini menjadi standar kualitas guna memberikan layanan yang profesional dengan hasil terbaik. Selain pendidikan, syarat lain penting yang harus dimiliki adalah kepribadian. Pada dasarnya, setiap orang memiliki karakteristik kepribadian masing-masing. Perbedaan ini tidak menjadi dasar penelitian apakah suatu kepribadian dapat disebut baik ataupun buruk, karena kepribadian merupakan sesuatu yang diperoleh (given) dari kondisi yang tidak dapat dihindari dari setiap individu. Kepribdian terbentuk sebagai hasil interaksi antara faktor genetik dan herediter (nature $\mathcal{E}$ nurture) sepanjang hidupnya serta kebudayaan dan lingkungan (Wade \& Tavris, 2005 \& Honigman, 1967). Oleh karena itu, tidak tepat untuk mengukur kepribadian dengan norma yang berlaku umum. Kepribadian akan lebih tepat digolongkan ke dalam konteks tertentu, seperti pekerjaan atau profesi.
Seseorang yang dikatakan memiliki kepribadian yang baik dalam pekerjaanya berarti sesuai dengan tuntutan pekerjaan yang harus dilakukannya, bukan dalam kategori norma sosial yang berlaku umum. Boleh jadi, orang yang tepat kepribadiannya untuk suatu pekerjaan, tetapi tidak sesuai untuk pekerjaan yang lainnya. Beberapa kasus yang terjadi melaui tes psikologi dalam rekrutmen pegawai baru seringkali ditemukan adanya orang yang hampir selalu gagal dalam setiap psikotest, sehingga memunculkan stigma bahwa dirinya memang tidak dapat bekerja. Padahal, sesungguhnya yang terjadi adalah bahwa orang tersebut memilih pekerjaan yang selalu sama namun memiliki kepribadian yang tidak sesuai dengan pekerjaan yang dipilihnya.

Salah satu jenis profesi yang diteliti pada kajian ini adalah profesi guru pembimbing. Syarat untuk menjadi guru pembimbing adalah memiliki kelayakan akademik, yaitu lulus pada jenjang sarjana bimbingan konseling atau memiliki sertifikat kewenangan yang diakui. Guru pembimbing adalah profesi yang ba- 
nyak tertumpu kepada pelayanan, sehingga termasuk kelompok profesi penolong (helper). Meskipun syarat akademik sudah dianggap memadai, sesungguhnya ada persyaratan penting yang juga seharusnya dimiliki untuk menjalankan tugasnya, yaitu memiliki kepribadian sebagai helper.

Bukanlah hal yang mudah untuk dapat memberikan pertolongan dengan baik. Sebagai pribadi, guru pembimbing juga manusia yang tidak luput dari masalah, sementara dalam pelaksanaan tugasnya dia harus memberikan pertolongan atas masalah yang dihadapi oleh orang lain. Bagi orang yang memiliki kepribadian yang sesuai, hal ini tidak akan menjadi kendala karena tetap mampu memberikan layanan yang baik.

Tempat mendidik para calon guru pembimbing adalah Jurusan Bimbingan Konseling yang termasuk salah satu jurusan di Fakultas Ilmu Pendidikan. Di tempat ini, para mahasiswa belajar untuk dapat melaksanakan bimbingan dan konseling, terutama di sekolah-sekolah. Selain diharapkan memiliki pengetahuan dan keterampilan dalam ilmu konseling, mahasiswa juga dibina untuk memiliki kepribadian yang sesuai. Namun demikian, pembinaan ini cukup banyak rintangan, karena mahasiswa adalah remaja yang sudah memiliki karakter sendiri sebagai hasil dari proses sebelumnya. Boleh jadi, mahasiswa pada awalnya sudah memiliki karakteristik kepribadian yang mengarah kepada kepribadian seorang helper, atau mungkin juga belum.

Permasalahan dalam penelitian ini adalah: (1) bagaimana profil kepribadian mahasiswa Jurusan Bimbingan Konseling di FIP UNJ? (2) komponen kepribadian mana yang paling dominan dalam keperibadian mahasiswa Jurusan Bimbingan Konseling di FIP UNJ?

Untuk mendukung penelitian ini, kajian teori yang digunakan adalah sebagai berikut.

a. Definisi dan Konsep Kepribadian

Kepribadian dalam psikologi merupakan sesuatu konsep yang sentral, bahkan menjadi sinonim dengan psikologi itu sendiri (Moghaddam, 2005: 195). Istilah seperti ego, extrovert dan neuroticism merupakan istilah yang populer dan dikenali sebagai psikologi. Kepribadian meliputi berbagai variasi potensi yang tidak berbatas pada seseorang untuk melakukan berbagai aktivitas, bagaimana seseorang menyelesaikan masalah, pengalaman emosi, gaya mereka berinteraksi dengan orang lain, dan cara-cara seseorang berefleksi diri (self reflection) (Moghaddam, 2005: 195).

Dalam psikologi, pembahasan mengenai tingkah laku yang kompleks disempitkan dengan dalam istilah sifat-sifat yang meliputi tingkah laku konsisten yang terus-menerus (long lasting consistency) (Moghaddam, 2005 : 195). Beberapa pakar psikologi membuat kesimpulan bahwa kepribadian dapat diikat (captured) dalam lima kelompok sifat, yang disebut dengan Big five.

Di antara banyak pakar psikologi, Gordon W. Allport merupakan pakar psikologi yang sangat intensif meneliti kepribadian (Wade \& Tavris, 2005: 48). Allport sangat menekanankan kepada sifat (traits) dan telah menyusun, serta menemukenali 18.000 kata sifat, kemudian meringkasnya dalam sejumlah kata sifat dan menyusun kategori sifat (Howard \& Howard 2001 :29). Pada mulanya, Allport membedakan central traits dan secondary traits.

Central traits adalah sifat yang merefleksikan suatu karakteristik mengenai cara orang dalam bertingkah laku, cara menghadapi orang lain, bereaksi terhadap situasi baru. Misalnya, ada orang yang melihat dunianya penuh dengan permusuhan dan tempat yang berbahaya, sementara orang lain melihat dunia sebagai tempat yang menyenangkan. Menurut Allport, dalam diri manusia terdapat lima sampai sepuluh central traits. Secondary traits, yaitu aspek kepribadian yang lebih dapat berubah, seperti minat terhadap jenis musik, kebiasaan, opini, dan kegemaran. Allport melakukan pendekatan yang sebagian besar bersifat intuitif dan didasarkan kepada studi kasus, bukan didasarkan kepada pengukuran psikometrik dalam jumlah yang besar.

Cattel dan Eysenck menggunakan prosedur statistik untuk meneliti sifat-sifat kepribadian. Prosedur tersebut pada awalnya dilakukan oleh Galton dan Pearson dengan menggunakan teknik statistik korelasi (Wade dan Tavris, 2005: 48). Cattel sangat menekankan prosedur statistik, terutama menganalisis faktor untuk menemukenali tema-tema umum yang mendasari kepribadian. Cattel mengerucutkan ribuan kata-kata sifat yang disusun Allport menjadi 16 faktor atau tema saja, dan menyebutnya dengan ujian 16 faktor kepribadian (sixteen personality test/16 PF)

Pengembangan selanjutnya dilakukan oleh Eysenck. Ia menggunakan angket ujian mandiri (self test) dengan tetap sama menggunakan prosedur statistik dalam mengeksplorasi karakteristik yang diwariskan. Eysenck juga menyarankan untuk menyusun hirarki elemen dari struktur kepribadian yang terdiri dari kebiasaan, sifat-sifat, dan tipe. Titik awalnya adalah level rendah pada hirarki yang merupakan respon-respon yang dapat diamati seperti penolakan terhadap penawaran untuk pesta, 
makan sendirian, serta menghabiskan waktu dengan membaca, bukan dengan bersosialisasi dengan orang lain. Korelasi di antara bentuk respon-respon kebiasaan asas dari sifat-sifat, misalnya menarik diri (withdrawn) serta keterampilan sosialisasi yang rendah, menjadi dasar dari tipe. Berdasarkan kajian yang ekstensif dari Eysenck, dapat disimpulkan bahwa kepribadian dicirikan dengan tiga dimensi, yaitu (1) introversion/ektroversion, (2) stability/neuroticism, dan (3) impuls-control/psychoticism. Eysenck Personality Questionaire telah diterjemahkan dan digunakan dalam berbagai kajian dengan budaya yang berbeda.

b. Komponen Kepribadian

Warren Norman pada tahun 1960-an telah meringkas sifat-sifat kepribadian dengan memperkenalkan "Big five". Meskipun melalui banyak pro dan kontra, namun pada tahun 1990-an tampaknya para peneliti kepribadian setuju mengenai ide tentang lima faktor utama dari kepribadian, yaitu: (1) agreeableness (kedapatsetujuan), (2) conscientiousness (kehati-hatian), introversion/extroversion, neuroticism, dan (3) openess to experience (keterbukaan kepada pengalaman). Kesimpulan ini merupakan pencapaian yang besar dalam bidang psikologi (Moghadam, 2005: 203; Howard \& Howard, 2001: 29; Wade \& Tarvis, 2005: 49).

Secara definitif, neuroticism diartikan sebagai kecenderungan untuk terfokus kepada aspek negatif dalam diri (Watson, 2000). Neuroticisme menggambarkan perbedaan individual dalam penyesuaian dan stabilitas emosi (Zhao \& Siebert, 2006). Orang yang memiliki skor neuroticisme yang tinggi cende-rung memiliki beberapa emosi yang negatif, misalnya keraguan, permusuhan, kesedihan, kesadaran pribadi, impulsif, dan mudah tersinggung (Costa \& Mc Crae, 1992). Sebaliknya, orang yang memiliki skor yang rendah dalam Neurotiscisme adalah orang yang yakin diri, tenang, jarang marah, dan rileks.

Orang ekstravert dicirikan sebagai orang yang percaya diri, dominan, aktif dan pencari kesenangan (Baker et al. 2006). Sejalan dengan pendapat itu, orang yang ekstrovert terlihat asertif, dominan, energik, aktif, peramah dan antusiastik (Costa \& McCrae, 1992). Orang yang memiliki skor ekstraversi yang tinggi cenderung bergembira, menyukai orang banyak dan keramaian, serta mencari kegairahan dan rangsangan. Sebaliknya, orang yang memiliki skor ekstraversi yang rendah lebih menyukai kesendirian dan dicirikan sebagai orang yang tidak ramah dan pendiam (Zhao \& Siebert, 2006).

Orang yang terbuka dicirikan dengan orang yang memiliki keinginan untuk tahu dan cenderung mencari pengalaman baru dan mencari ide-ide baru (Costa \& McCrae, 1992; Zhao \& Siebert, 2006). Orang yang memiliki skor yang tinggi dalam keterbukaan digambarkan sebagai orang yang kreatif, inovatif, imajinatif, dan reflektif. Sebaliknya, orang yang rendah dalam keterbukaan dicirikan sebagai orang yang konvensional, memiliki minat yang sempit, dan tidak analitis.

Kedapatsetujuan merupakan orientasi hubungan antar pribadi (interpersonal). Orang yang memiliki kedapatsetujuan yang tinggi dicirikan sebagai orang yang mempercayai, memaafkan, peduli (caring), pemurah (altruistic), dan mudah tertipu. Selain iu, orang tersebut juga memiliki nilai kooperatif dan menyukai hubungan interpersonal yang positif. Sebaliknya, orang yang memiliki skor yang rendah dicirikan sebagai orang yang manipulatif, berpusat ke diri (self cendetered), pencuriga, dan licik (Costa \& McCrae,1992; Digman, 1990) Kedapatsetujuan sangat relevan dalam situasi yang melibatkan keterlibatan interaksi atau kerjasama dengan orang lain (Barrick \& Mount, 1991).

Meskipun kedapatsetujuan akan membuat orang tampak memiliki kepercayaan dan akan membantu sikap positif, serta hubungan kerja yang kooperatif, akan tetapi taraf yang tinggi dari kedapatsetujuan akan mencegah keinginan untuk berusaha untuk menawar dengan alot (hard bargains), mencari peminatan pribadi (one's own selfinterest), dan mempengaruhi atau memanipulasi orang lain demi keuntungan pribadi (Zhao \& Siebert, 2006). Kebutuhan yang tinggi untuk afiliasi sebagai komponen dari kedapatsetujuan akan dapat merusak karir (Mc Clelland \& Boyatzis, 1982).

Pembahasan mengenai kehati-hatian termasuk aspek, seperti kompetensi, keteraturan, dutifulness (penuh tanggung jawab), upaya meraih prestasi, disiplin pribadi, penuh pertimbangan, dan kecermatan dalam mengambil keputusan (Clark \& Robertson, 2005). Kehati-hatian mengindikasikan posisi individu dalam organisasi, ketekunan, kerja keras, dan motivasi dalam mengejar pencapaian tujuan (Zhao \& Siebert, 2006).

c. Faktor-Faktor Yang Berpengaruh Kepada Pembentukan Kepribadian

Faktor-faktor yang berpengaruh terhadap pembentukan kepribadian secara singkat adalah (1) genetik; (2) lingkungan; (3) pengalaman yang bersifat internal, dan kebudayaan (Wade \& Tavris, 2005); serta (5) lingkungan (Honigman, 1967). Untuk lebih jelasnya, berikut penjelasan mengenai faktorfaktor yang berpengaruh terhadap pembentukan 
kepribadian.

Perdebatan mengenai nature dan nurture dalam psikologi merupakan kontraversi yang sudah berlangsung lama, sekarang ini banyak pakar psikologi yang mengakui bahwa gen-gen adalah unitunit dasar dari turunan (heredity), sebagian variasi sifat ditentukan oleh gen-gen tersebut dan setengah lainnya oleh lingkungan dan pengalaman (Wade \& Tavris, 2005) .

Berdasarkan social-cognitive theory, kepribadian adalah hasil dari interaksi antara aspek lingkungan dan aspek invidual. Bukti-bukti yang mendukung kepada pengaruh yang besar dari orang tua terhadap kepribadian dan tingkah laku anak-anaknya adalah: (a) kajian terhadap tingkah laku genetik menemukan bahwa lingkungan keluarga hanya memberikan sedikit pengaruh terhadap kepribadian, (b) sedikit saja orang tua yang memiliki pola pengasuhan yang konsisten terhadap anak-anaknya dengan kontinyu, serta (c) kalaupun orang tua berusaha untuk konsisten, hanya sedikit hubungan antara apa yang mereka lakukan dengan bagaimana anak-anak mendapatkannya dari orang lain.

Lingkungan yang sangat besar memberikan pengaruh terhadap remaja adalah kelompok sebaya (peer). Umumnya, anak-anak dan remaja bertingkah laku yang berbeda dengan orang tuanya, mereka hanya ingin sama dengan teman-teman yang lain. pengasuhan yang baik dalam keluarga akan memberikan efek yang baik terhadap anak berupa munculnya rasa percaya (trust), percaya diri, dan perasaan aman. Implikasinya adalah mereka akan lebih mandiri, memiliki keberanian, termasuk mengambil resiko dan pantang menyerah. Sebaliknya buruknya pengasuhan akan menyebabkan beberapa efek seperti yang telah dijelaskan sebelumnya, dan implikasinya terhadap kepribadian overt mereka (Honigman 1967: 107).

Banyak pakar psikologi meyakini apabila kepribadian seseorang amat dipengaruhi oleh kebudayaan. Orang-orang dari kebudayaan yang individualistic memiliki perbedaan dengan kebudayaan kolektif. Budaya kolektif sangat menekankan harmoni dan meletakan tujuan kelompok di atas tujuan perorangan, sedangkan budaya individualistik sebaliknya. Beberapa pakar psikologi membuat kesimpulan bahwa budaya yang membentuk kepribadian (Branco, 2003:251; Wade \& Tarvis, 2005:59). Budaya melalui sosialisasi akan membentuk harapan, ketakutan dan perhatian individu (Honigmann, 1967: 68). Kardiner manyatakan bahwa kepribadian pada dasarnya dibentuk oleh pengalaman-pengalaman umum di lembaga primer (primary institution).

Anak-anak dalam suatu sistem sosial tertentu menemukan cara untuk memperoleh makanan, menerima kasih sayang, melakukan toilet training, tergantung, dan juga permusuhan. Pengalamanpengalaman tersebut pada awalnya diperoleh dalam keluarga. Perlakuan awal dalam keluarga akan membuat mereka memiliki kepribadian tertentu.

Pakar-pakar psikologi humanistic sangat memperhatikan pengalaman subjektif peribadi dan keinginan untuk berubah (Wade \& Tarvis, 2005 63). Mereka menekankan kepada potensi manusia dan kekuatan kemanusiaan (human nature). Maslow memiliki konsep "Peak experience" (pengalaman kemuncak), Carl Rogers menekankan kepada "unconditional positive regard", sedangkan Rollo May menekankan kepada berberapa tantangan inheren pada eksistensi manusia yang menjadi keputusan dari kebebasan berkeinginan, misalnya pencarian makna hidup. Meskipun dikritik karena tidak dapat diukurkan, tetapi didukung oleh beberapa terhadap aspek positif dari kepribadian, termasuk ketahanan pada saat ditimpa kemalangan (adversity).

\section{METODE PENELITIAN}

Penelitian ini merupakan jenis penelitian deskriptif dengan pendekatan kuantitatif, karena akan memberikan gambaran secara utuh mengenai profil kepribadian responden. Penelitian ini dilaksanakan di Jurusan Bimbingan Konseling Fakultas Ilmu Pendidikan Universitas Negeri Jakarta pada bulan Juli sampai dengan September 2008.

Populasi penelitian adalah mahasiswa yang terdaftar di Jurusan Bimbingan Konseling Fakultas Ilmu Pendidikan Universitas Negeri Jakarta pada tahun 2008, terutama mahasiswa yang berada di semester III sampai dengan semester VII, karena saat ini berada di semester ganjil. Hal ini didasarkan kepada pertimbangan bahwa mahasiswa yang baru masuk di semester I masih dalam tahap awal masa studi dan mereka baru mulai belajar mengenai ilmu Bimbingan dan Konseling, sehingga belum cukup mengalami internalisasi dari pengetahuan yang diperolehnya. Sementara itu, mahasiswa yang tercatat sedang berada di semester IX umumnya sudah tidak lagi ada di kampus, karena mereka sedang dalam proses penyusunan skripsi sehingga agak menyulitkan untuk mengisi angket peneltian yang disediakan. Dengan demikian jumlah total dari populasi adalah adalah 107 orang. Dari seluruh populasi yang ada akan dipilih beberapa orang mahasiswa sebagai sampel. 
Teknik pemilihan sampel menggunakan teknik acak proporsional (proporsional random sampling).

Berdasarkan data administrasi, diketahui bahwa mahasiswa semester III berjumlah 52 orang, mahasiswa semeter $\mathrm{V}$ berjumlah 33 orang dan mahasiswa semester VII berjumlah 52, dengan demikian jumlah seluruh populasi dalam penelitian ini adalah 117. Pada awalnya seluruh populasi akan menjadi sampel penelitian, sehingga merupakan sensus, akan tetapi dari seluruh angket yang disebar, hanya kembali 44, terdiri dari 14 mahasiswa semester, 17 orang mahasiswa semester $\mathrm{V}$ dan 11 orang mahasiswa semester VII. Jumlah 44 orang untuk penelitian yang bersifat survey dianggap sudah memadai untuk menjadi sampel (Gay \& Airasian, 2003)

Data yang akan dikumpulkan merupakan data deskriptif yang diperoleh dengan menggunakan angket. Angket yang digunakan adalah Mini Markers, yaitu instrumen kepribadian yang didasarkan kepada teori Big five personality, dengan format yang sederhana. Angket ini dikontruksi oleh Goldberg pada tahun 1985 (Saucier, 1994; Costa \& McRae: 1992; Clark \& Robertson: 2005) yang menggunakan bahasa Inggris. Karena sampel penelitian ini adalah mahasiswa yang berbahasa Indonesia, maka angket harus mengalami adaptasi. Adaptasi yang dimaksud terutama adaptasi bahasa, dengan prosedur yang telah ditetapkan. Pertama diterjemahkan ke dalam bahasa Indonesia, kemudian diterjemahkan kembali ke dalam bahasa Inggris atau mengalami back translation. Prosedur ini diharapkan akan mengurangi adanya kesalahan interpretasi dari butir asal soal yang telah disusun dalam bahasa aslinya. Uji validitas dan reliabilitas secara empirik menunjukan bahwa skor koeefisien korelasi item dalam Big five berikisar antara 0.35-0. 58 dan Reliabilitas Alpha adalah 0.89. Jumlah item dari angket ini adalah 40 item berbentuk skala likert dengan pilihan 1 sampai 9. Skor 1 berarti paling tidak sesuai dan skor 9 berarti paling sesuai.

Data yang terkumpul akan dianalisis dengan menghitung tendency central berupa rerata (mean) dan standar deviasi (SD). Berdasarkan hitungan tersebut, akan dapat ditentukan norma kelompok dan mengukur kecenderungan kelompok dalam kepribadian. Seluruh proses analisis data menggunakan SPSS versi 13.0.

\section{HASIL DAN PEMBAHASAN}

\section{Hasil Penelitian}

Berdasarkan penelitian yang dilakukan, maka hasil penelitian ini dilaporkan dalam bentuk deskriptif.
Secara deskriptif, dapat dilihat bagaimana rerata nilai dari kepribadian yang dimiliki mahasiswa pada tabel 1

Tabel 1. Nilai Rerata Kepribadian

\begin{tabular}{|c|l|c|}
\hline No & \multicolumn{1}{|c|}{ Faktor } & Nilai Rerata \\
\hline 1 & Ekstraversi & 6.27 \\
\hline 2 & Kedapatsetujuan & 6.64 \\
\hline 3 & Kehati-hatian & 5.85 \\
\hline 4 & Neuroticism & 5.86 \\
\hline 5 & $\begin{array}{l}\text { Keterbukaan terhadap } \\
\text { pengalaman }\end{array}$ & 6.3 \\
\hline
\end{tabular}

Berdasarkan tabel 1, dapat dilihat bahwa rerata nilai setiap subvariabel kepribadian umumnya berada pada rentang antara 5,85 sampai dengan 6,64 pada skala 1-9. Dengan demikian, mereka umumnya berada dalam ke tengah. Skor yang diperoleh berdasarkan pengukuran memperlihatkan bahwa skor tertinggi adalah kedapatsetujuan (agreeableness) sementara yang terendah adalah kehati-hatian. Profil ini pada dasarnya cukup mengkhawatirkan. Karena kehati-hatian merupakan komponen kepribadian yang penting, pada dasarnya diharapkan tinggi. Kehati-hatian atau kecermatan yang tinggi akan mereflesikan keteraturan, dutifulness (penuh tanggung jawab), upaya meraih prestasi, disiplin pribadi, penuh pertimbangan, dan kecermatan dalam mengambil keputusan. Sementara itu, skor agreeableness adalah skor rerata yang paling tinggi. Skor yang tinggi pada faktor ini menunjukan adanya ketidaktegasan, terlalu akomodatif, atau hanya berusaha untuk mengikuti kemamuan orang lain.

\section{Pembahasan}

a. Ekstraversi

Faktor ekstroversi dalam pengukuran kepribadian yang didasarkan kepada teori "Big Five Personality", pada dasarnya akan memberikan gambaran mengenai suatu rentang kepribadian yang terkait erat dengan kemampuan bersosial (sociability) (Howard \& Howard, 2002). Disebut rentang kepribadian, karena memiliki kontinuitas dari ekstrim kiri hingga ekstrim kanan. Sebagai contoh, skor ekstroversi yang tinggi berarti yang bersangkutan memiliki kepribadian ekstrovert (terbuka), sementara yang memiliki skor rendah berarti memiliki keperibadian introvert (tertutup). Sedangkan yang berada di tengah atau hanya memiliki kecenderungan, berarti memiliki kepribadian ambivert.

Dalam skala 1 - 9, skor 1 sampai 3 menunjukan introvert, 4 sampai 6 menunjukan ambivert. Apabila skornya adalah 7 - 9, berarti memiliki kepribadian ekstrovert. Dengan skor ekstraversi sebesar 6.27, secara singkat dapat dijelaskan bahwa mahasiswa 
Jurusan Bimbingan Konseling termasuk orang dengan kepribadian ektravert.

Skor ekstroversi yang tinggi menunjukan orang yang menyukai keramaian dan orang banyak. Selain itu, orang tersebut memiliki kemampuan sosial yang baik untuk dapat menerima orang lain dalam kelompoknya tanpa mengalami proses penyesuaian yang lama. Tingkah laku yang muncul yang membuat mahasiswa dapat terlibat dengan mudah dalam hubungan sosial adalah karena umumnya mahasiswa senang berbicara (mengobrol), memiliki antusias, hangat dan menyukai kesenangan. Sebailknya, orang dengan kepribadian intravert adalah orang yang memiliki kesenangan untuk menyendiri. Penampilannya secara umum terlihat sebagai orang yang sangat serius, pendiam, dan akan selalu berusaha untuk menghindari adanya keramaian.

Jenis kepribadian yang merupakan kelompok mayoritas adalah ambivert, atau tengah-tengah antara ekstravert dan introvert. Sifat yang tampak juga masih merupakan bentuk kecenderungan. Orang dengan kepribadian ambivert adalah orang yang dapat menikmati kehidupan ramai tetapi juga dapat menempatkan diri dalam kehidupan yang sepi dan menyendiri.

b. Kedapatsetujuan (Agreeableness)

Kedapatsetujuan merupakan faktor kepribadian yang berkaitan dengan kemampuan negosiasi. Kemampuan ini merupakan suatu kontinuum, antara penantang (chalenger), negosiator dan adapter. Seorang Chalenger adalah orang yang selalu tegas, melindungi diri, persisten, kompetitif bahkan agresif. Seringkali merupakan orang yang independan dalam hal pemikiran dan sangat berusaha untuk menjaga kepentingan pribadi dan memastikan bahwa dia merupakan penentu. Sementara negosiator adalah orang yang dapat merubah dan menukar antara kompetetif dan kooperatif. Dia umumnya orang yang menggunakan dan berusaha mencari win-win solution. Adapter atau dapat diartikan akomodatif adalah bentuk kepribadian yang sangat toleran, rendah hati dan cenderung untuk mengikuti kepentingan orang lain.

Skor kedapatsetujuan mahasiswa Jurusan Bimbingan Konseling adalah 6.84. Skor ini cukup tinggi dan hal in akan menunjukan bahwa mereka dicirikan sebagai orang cukup dapat mempercayai, memaafkan, peduli (caring), pemurah (altruistic), dan sisi buruknya mereka mudah tertipu untuk seorang calon konselor skor yang tinggi dari sifat sudah menunjukan kecenderungan kepribadian yang sesuai dengan tuntutan pekerjaan mereka ke depan, karena hal tersebut diperlukan bagi orang yang bekerja dalam pelayanan kemanusiaan.

c. Kehati-hatian

Faktor ini berkaitan dengan pengaturan diri dalam hubungannya dengan sistem fokus untuk mencapai suatu tujuan tertentu (Howard \& Howard, 2001). Rentang kehati-hatian mulai dari terfokus sampai dengan fleksibel. Sementara antar keduanya adalah imbang (balance).

Orang yang memiliki sifat terfokus akan menunjukan diri sebagai orang yang rajin, tekun dan memiliki disiplin yang tinggi. Pola kerjanya teratur, tertin dan serial. Orang tersebut akan terlihat memiliki perencanaan yang baik, dan berusaha keras untuk dapat mencapai tujuan melalui kerja keras. Sebaliknya, dengan sifat di atas, orang dengan sifat yang fleksibel akan memperlihatkan kecenderungan untuk santai (rileks dan tenang) dalam mencapai suatu tujuan. Dia mungkin orang yang suka menunda pekerjaan (procastinator), dapat mengerjakan banyak tugas (multitask) dengan terlibat dalam berbagai kegiatan dalam satu waktu tertentu. Sedangkan orang yang memiliki sifat imbang (balance) cenderung untuk menjaga keseimbangan antara kebutuhan kerja dengan keinginan personal dan berbagai peran melalui keseimbangan yang tepat.

Skor kehati-hatian mahasiswa Jurusan Bimbingan Konseling adalah 5, 85 dalam skala 9. Ini berarti bahwa mahasiswa memiliki kenderungan untuk seimbang (balance), berusaha dalam posisi seimbang antara untuk pencapaian target dengan tetap menjaga

d. Stabilitas emosi

Faktor ini tekait dengan stabilitas emosi dan daya tahan terhadap tekanan. Kontra dari stabilitas emosi adalah neuroticism, yang diartikan sebagai kecenderungan untuk terfokus kepada aspek negatif dalam diri (Watson, 2000). Neuroticisme menggambarkan perbedaan individual dalam penyesuaian dan stabilitas emosi (Zhao \& Siebert, 2006). Orang yang memiliki skor stabilitas emosi yang tinggi adalah orang yang yakin diri, tenang, jarang marah, dan rileks. Sebaliknya orang yang memiliki skor yang rendah adalah memiliki kecenderungan emosi yang negatif, misalnya keraguan, permusuhan, kesedihan, kesadaran pribadi, impulsif dan mudah tersinggung (Costa \& Mc Crae, 1992). Skor stabilitas emosi mahasiswa Jurusan Bimbingan Konseling adalah 5.86. Skor yang lebih tinggi dari skor Median, dengan demikian, dapat dikatakan bahwa mereka cenderung memiliki emosi yang stabil, lebih rileks, dan tidak mudah marah. Profile ini cukup baik, meskipun belum memiliki taraf yang diharapkan 
e. Keterbukaan terhadap pengalaman

Orang yang terbuka dicirikan memiliki keinginan untuk tahu dan cenderung mencari pengalaman serta ide-ide baru (Costa \& McCrae, 1992; Hao \& Siebert, 2006). Orang yang memiliki skor yang tinggi dalam keterbukaan digambarkan sebagai orang yang kreatif, inovatif, imajinatif dan reflektif. Sebaliknya orang yang rendah dalam keterbukaan dicirikan konvensional, memiliki minat yang sempit dan tidak analitis.

Keterbukaan terhadap pengalaman merupakan faktor kepribadian yang berkait erat dengan keinginan tahu (Curiosity).Skor Keterbukaan terhadap pengalaman mahasiswa Jurusan Bimbingan Konseling adalah 6,3.

\section{Pembahasan}

Berdasarkan instrumen mini markers atas profil kepribadian mahasiswa Jurusan Bimbingan dan Konseling didapatkan bahwa sifat dominan dari kepribadian mereka adalah kedapatsetujuan. Hal ini menunjukan kecenderungan untuk menjadi adapter, meskipun ada sifat baik yang menononjol berupa skor keterbukaan yang juga tinggi (Skor, 6.3) Kepribadian akan memberikan dasar bagi terbentuknya kompetensi akademik, berupa minat yang tinggi terhadap pengetahuan.

Seorang yang memiliki profesi penolong (helper) dan pelayanan kemanusiaan, (konselor merupakan salah satu bentuk dari profesi ini ) kompetensi yang penting harus dimiliki adalah "pemahaman interpersonal yang tinggi" (Spencer \& Spencer: 1993). Kompetensi ini dapat terlihat dari : (1) merasakan dan menerima perasaan dan mood orang lain; (2) menggunakan pemahaman yang didasarkan kepada hasil menyimak dan observasi untuk mempersiapkan dan memperikirakan reaksi orang lain; (3) memahami sikap, minat, keinginan dan perspektif orang lain; dan (4) memahami penyebab yang melatari kemunculan sikap dan pola tingkah laku dan masalah tertentu yang muncul dalam proses jangka panjang.

Kompetensi tersebut merupakan manifestasi dari refleksi kepribadian seseorang. Dalam kaitannya dengan dasar konseptual dari teori "Big Five theory" maka kompetensi tersebut dapat dicapai lebih mudah untuk orang yang memiliki kecenderungan untuk Ekstrovert memiliki kehati-hatian yang tinggi serta terbuka dengan pengalaman (openness to experience).

Selain genetik, factor yang sangat berpengaruh pada proses pembentukan kepribadian adalah lingkungan, pengalaman yang bersifat internal, dan kebudayaan (Wadex Travis: 2005). Untuk faktor genetik, disini tidak akan dibahas lagi karena merupakan sesuatu yang sudah bersifat inherent. Para mahasiswa tersebut datang dari genetik yang sudah mereka terima. Untuk faktor lingkungan, pembahasan mendalam pada lingkungan di usia remaja, karena untuk mahasiswa yang berada dalam rentang usia 19 th -22 th yang berada pada tingkat usia remaja akhir (Hurlock, 1992). Usia ini berada dalam kondisi transisi menuju dewasa, tetapi masih sangat dipengaruhi oleh teman sebaya (Santrock, 2002).

Faktor yang mungkin sangat perlu diperhatikan adalah pengalaman internal, yang akan memberikan dampak kepada pembentukan keperibadian mereka. Sebagai mahasiswa yang belajar mengenai kondisi psikologi manusia serta kegiatan layanan atas manusia, umumnya akan memiliki keinginan tahuan atas masalah yang dirasakan. Sebagai bagian dari pilihan karir pendidikan merupakan dasar ke arah karir. Seseorang memilih karir karena memiliki pengalaman tertentu

\section{PENUTUP}

\section{Kesimpulan}

Setiap profesi memiliki karakter pekerjaan khusus, hal ini yang mempersyaratkan orang yang memilih profesi untuk sesuai dengan tugas fungsinya. Salah satu syarat penting adalah kepribadian. Kepribadian disimpulkan sebagai berbagai variasi potensi yang tidak berbatas pada seseorang untuk melakukan berbagai aktivitas, akan memberikan kontribusi yang nyata terhadap kinerja seseorang, sehingga sangatlah penting adanya kesesuaian antara kepribadian dengan pekerjaan. Demikian halnya dengan profesi guru pembimbing atau konselor sekolah, dengan seperangkat tugas dan tanggung jawab yang khas dituntut untuk melaksanakannya semaksimal mungkin.

Meskipun sama-sama guru sama dengan guru mata pelajaran, tetapi guru pembimbing tetap unik, sehingga akan berbeda persyaratan antara keduanya. Guru pembimbing lebih menitikberatkan kepada tugas pelayanan terhadap kemanusiaan, bukan sebagai agen transformasi pengetahuan saja. Untuk itu mengikut standar kompetensi helper harus memiliki kompetensi kepribadian yang harus sangat menonjol seperti pemahaman antar pribadi, yang didalamnya meliputi kemampuan berempati, kemampuan menyimak, memiliki kepekaan terhadap orang lain, peduli terhadap perasaan orang lain serta memahami diagnosa. Kompetensi ini bukan merupakan sesuatu yang mudah, selain memiliki kecenderungan bawaan tetapi juga diperoleh melalui hasil dari latihan dan pendidikan serta lingkungan.

Profil seperti ini untuk konselor meskipun 
bukan merupakan gambaran yang ideal, tapi sudah cukup baik untuk terus dikembangkan. Modalitas mahasiswa untuk menjadi konselor/guru pembimbing dari aspek kepribadian sudah cukup dimiliki. Sebagai orang yang akan bekerja di bidang pelayanan kemanusiaan, mahasiswa sudah memiliki dasar yang tepat. Dengan demikian, kegiatan layanan yang diberikan akan cukup optimal. Apalagi apabila ditunjang dengan pengetahuan dan keterampilan yang tinggi.

\section{DAFTAR PUSTAKA}

Clark, I., \& Robertson, I.T. (2005). A Meta-analytic review of the Big Five personality factors and acident involvement in occupational and nonoccupational setting. Journal of Occupational and Organizational Psychology, 78: 355-376.

Costa, P.T. Jr., \& McCrae, R.R. (1992/=). Revised neo personality inventory (NEO PI-R) and neo five factor inventory (NEO-FFI): Professional manual. Lutz, FL: Psychological Assessment Reosurces, Inc.
Gay, L.R., \& Airasian, P. (2003). Educational research, competencies for analyses application. New Jersey, Merril Prentice Hall

Honigmann, J.J. (1967). Personality in culture. New York: Harper \& Row, Publisher

Howard, P.J., \& Howard J.M. (2001). The owner's manual for personality at work. Austin: Bard Press.

Moghadam, F. M. (2005). Great ideas in psychology: a cultural and historical introduction. Oxford: One World.

Neuman, W.L. (2003). Social research methodes: qualitative and quantitative approaches, fifth edition. Boston: Allyn \& Bacon.

Saucier, G. (1994). Mini-markers: A brief version of goldberg's unipolar big five markers. Journal of Personality Assessment 63 (3). 505-516

Spencer L.M., \& Spencer, S.M. (1993). Competence at work, models for superior performancer. New York. John Wiley \& Son.

Wade, C., \& Tavris, C. (2005). Invitation to psychology. 3 rd ed. New Jersey: Pearson Prentice Hall.

Watson, D. (2000). Mood and temperament. New York: The Builford Press. 